Social Work/Maatskaplike Werk Vol 57 No 2; Issue 7

http://socialwork.journals.ac.za/pub

doi:http://dx.doi.org/10.15270/52-2-931

THE EXPERIENCES OF ABUSED OLDER PERSONS IN RESOURCE-POOR SETTINGS

Gcotyiswa Mtiya-Thimla, Mariette van der Merwe

Elder abuse is a worldwide problem, aggravated by the global increase in the older population. This paper reports on a qualitative descriptive study done within the broad framework of intervention research. It explores the experiences of abused older persons in resource-poor settings in Bloemfontein, South Africa. Data were collected during individual semi-structured interviews and intervention sessions. The honest accounts of participants revealed the raw pain and distress of their experiences of abuse. In the light of the serious multidimensional reactions to elder abuse described in this article, consistent and coordinated social work services offered to older person who are abused is recommended.

Keywords: elder abuse, bio-ecological approach, global ageing, resource-poor settings, social work, trauma 



\section{THE EXPERIENCES OF ABUSED OLDER PERSONS IN RESOURCE-POOR SETTINGS}

\section{Gcotyiswa Mtiya-Thimla, Mariette van der Merwe}

Mrs Gcotyiswa Mtiya-Thimla, Postgraduate student, Compres, Faculty of Health Sciences, North-West University, Potchefstroom, South Africa.

Prof. Mariette van der Merwe, Centre for Child, Youth and Family Studies, Compres, Faculty of Health Sciences, North-West University, Potchefstroom, South Africa.

Keywords: elder abuse, bio-ecological approach, global ageing, resource-poor settings, social work, trauma

\section{INTRODUCTION}

Elder abuse is a worldwide problem (Chaurasia \& Srivastava, 2020:3; Yon, Mikton, Gassoumis \& Wilber, 2017:147), aggravated by the global increase in the older population (Kotzé, 2018:1; Kumar, 2016:572). In this regard, Hillier and Barrow (2017:18) talk about the "global aging revolution." It is projected that by the year 2050 the global population aged 65 and older will increase by threefold to 2 billion (Rishworth, Elliott \& Kangmennaang, 2020:4). In the South African context, Goodrick and Pelser (2014:649) refer to "the greying of a rainbow nation."

An older person is generally viewed as a person who is 60 years and older (Barbelet, 2018:2; Older Persons Amendment Bill, 2017:230). In South Africa older persons have always been perceived as a vulnerable and marginalised group (Frisoli, 2016:3; Human Rights Watch, 2016; Older Persons Act No. 13 of 2006). Many older persons do not have access to basic services, especially in resource-poor settings. Consequently, their fundamental rights as outlined in the Constitution (1996) are not fulfilled (South African Human Rights Commission, 2015). Being abused further violates the rights and wellbeing of older persons.

The incidence of elder abuse in South Africa is not clear. Often cases of elder abuse are not registered and when reported to the police, such cases are classified under general or indecent assault or murder (Kotzé, 2018:358; Roos \& Wheeler, 2016:519). This was also true in the resource-poor settings in the Bloemfontein area where this study was done. The first author co-ordinates services to older persons in the Free State province and was aware of the extent of the problem based on referrals and intergenerational dialogues in the province. DePrince and Jackson (2020:151) point to the fact that elder abuse generally does not receive the same attention from scholars as child maltreatment and other forms of interpersonal violence.

In the broad context of global ageing, little is known about the experiences of abused older persons (Kotzé, 2018:1; Yon et al., 2017:147). There is more research on theories of elder abuse, victimisation and on prevention and intervention strategies (Mathew \& Nair, 2017:29; Santos et al., 2019:2). Hillier and Barrow (2017:42) importantly point out that "it is time to move away from hard, scientific data" and listen to the voices of older persons about their life experiences. This is echoed by DePrince and Jackson (2020:155), who call for inclusion of the "voices of older victims" on aspects related to elder abuse.

Exploring older persons' experiences of elder abuse was aimed at getting more insight into the problem of elder abuse. In her seminal work on shattered assumptions, Janoff-Bulman (2002:4) stated that there are individualised responses to traumatic exposure but there are broad similarities from which people can learn. If social workers know more about the possible experiences of the abused older persons, social work interventions can be refined to address such experiences.

This paper reports on one part of broader intervention research. The aim of this part of the research was to explore the experiences of abused older persons in resource-poor settings in, Bloemfontein, Free State 
province. The research question that guided this part of the research was: What themes can be identified when exploring the experiences of abused older persons regarding the abuse and associated trauma? This paper will discuss the concepts elder abuse, trauma and resource-poor settings. The theoretical framework for the study, the bio-ecological approach and conservation of resources theory, will be outlined briefly and also linked to the findings. Research methodology will be delineated and then the findings will be reported with a discussion and conclusion.

\section{CLARIFICATION OF CORE CONCEPTS}

\section{Elder abuse}

Elder abuse is "a single or repeated act, or lack of appropriate action that occurs within any relationship where there is an expectation of trust and that causes harm or distress to an older person" (WHO, 2013:126). This study was limited to physical and sexual abuse. Other types of elder abuse are financial exploitation, psychological and emotional abuse, neglect and systemic abuse (Kotzé, 2018:3). Phelan (2020:6) describes a type of elder abuse linked to residential care, namely resident-to-resident abuse, which has elements of social exclusion and humiliation.

\section{Trauma}

Elder abuse is a traumatic experience. De Prince and Jackson (2020:152) discuss the need to understand the "nexus between elder abuse and traumatic stress." According to Bailey and Brown (2020:110). the term trauma can be used interchangeably for the event causing the trauma and also for the consequences of such an event. Welsh (2018:1) describes trauma as "an emotional response to a disturbing or distressing event or series of events." Taylor (2014:3) states that "Traumatic events are usually defined as being life threatening, exceeding the victim's normal resources."

\section{Resource-poor settings}

In South Africa resource-poor settings are communal areas that have low stores of social, natural, financial and human capital (Clark \& Kiates, 2008:65). For this research a resource-poor setting is seen as a context where people have low stores of material resources, including financial constraints and inadequate housing. They have limited access to services. Conditions in their environment could include violence and crime, which would lead to their feeling unsafe. The lack of tangible resources could lead to resource loss of non-tangible assets such as social networks and intrapersonal attributes such as a sense of personal agency.

Hillier and Barrow (2017:6) refer to the work of Cruikshank (2013) on subsistence cultures (which could be likened to resource-poor settings) where older persons can become a burden when they "outlive their usefulness." They can then be exposed to isolation, abuse and neglect.

\section{THEORETICAL FAMEWORK}

\section{Bio-ecological approach}

The bio-ecological approach is used as a lens to understand trauma (Lopez Levers, 2012) and also to view the experience of older persons (Greenfield, 2012). Hillier and Barrow (2017:3) emphasise the importance of understanding the context of older persons, which links with the bio-ecological approach of Bronfenbrenner (Rosa \& Tudge, 2013:243) and the interrelatedness between people and their life settings.

In the context of elder abuse, Bronfenbrenner's conceptualisation of the chronosystem offers a way to look at "collective life issues" (Gitterman, 2017:284) which affect individuals, families or communities. Older persons have often been adversely affected by the socio-political history of South Africa, with special reference to apartheid, which would count as a collective life issue. Gitterman (2017:283) also uses the concept 'birth cohorts', which refers to "people born at the same period of time" who are affected by its "generational events." It will be important for social workers to take such generational events into 
account, as well as the individual effect they had on each older person. Furthermore, each person's life history will play a role in current functioning in the different systems, especially after elder abuse. Healthy interactions in the microsystem and a good flow in proximal processes are strong protective factors for older persons in the aftermath of elder abuse. Their vulnerability increases when there are not adequate protections and implementation of policies on the macrosystem level.

\section{Conservation of resources}

Hobfoll's conservation of resources (COR) theory is a stress theory which has been used in many contexts (Chen, Westman \& Hobfoll, 2015:95). Greenfield (2012:3) employs a bio-ecological lens to view the flow of resources in the lives of older adults. Whereas Hobfoll (2011:117) distinguishes between material resources (energy and objects), condition resources and personal resources, Greenfield (2012:2) refers to psychological resources (such as a strong sense of agency, positivity, self-worth), biological and social resources. This author emphasises the "fit" between individuals and the environment which can help them to deal with challenges in their milieus.

People are continually managing resources, and attempting to build resource reservoirs (Hobfoll, 2011:117). Greenfield (2012:2) cautions that resources of older persons cannot always measure up against what is needed to survive in their physical and social environments. In some communities where there are absolute and other forms of poverty, the momentum of resource loss is much faster than resource gain. In this regard Hobfoll (2011:117) says that "those with fewer resources are more vulnerable to resource loss and less capable of resource gain." In South Africa older persons living in resource-poor settings do not always have access to quality care that includes safe environments, healthy food, exercise and care facilities. Being exposed to trauma worsens their situation and aggravates resource loss (Kotzé, 2018:358; Zaidi, 2015:3). Victims of elder abuse must acquire and conserve personal strength and social network bonds to adapt in the aftermath of trauma.

Research methodology was planned and implemented to explore the experiences of abused older persons qualitatively with this theoretical framework in mind.

\section{RESEARCH METHODOLOGY}

\section{Approach and design}

This research followed a qualitative approach. Qualitative research typically answers questions based on meaning, experiences and perceptions of participants (Hammarberg, Kirkman \& De Lacey, 2016:499). In the broad framework of intervention research, a qualitative descriptive design was used to explore the experiences of abused older persons. The qualitative descriptive design supports data collection to obtain information "directly from those experiencing the phenomenon under investigation" (Bradshaw, Atkinson \& Doody, 2017:1).

\section{Sampling}

Systematic random sampling was used to select 15 participants from the elder abuse register of the Department of Social Development (DSD), Bloemfontein. At the time of sampling, the DSD register recorded 54 names of abused older persons. From the first name on the list every third person was selected. More participants could have been included if data saturation had not been reached. Although trauma is a highly individualised experience, the same kind of phrases and descriptions in the narratives of participants were detected by the time 15 participants were included, which pointed to data saturation.

The inclusion criteria were that participants had to be between the ages of 60-80 years, victims of elder abuse within the 2017 - 2018 timespan, between 6 weeks and 2 years after the abuse happened, and they had to live in a resource-poor setting. This study was limited to physical and sexual elder abuse. Prospective participants who had formal diagnoses of post-traumatic stress disorder or dementia were excluded, as they were deemed too vulnerable. 


\section{Data collection and analysis}

Each participant was involved in an individual semi-structured interview to explore their experiences of elder abuse. Thereafter each participant took part in six intervention sessions where more information was obtained about their experiences of abuse. All these contacts took place in their homes. The interview was guided by a question about their experiences of the elder abuse, followed with probing questions and a question on the support they received.

The researcher is proficient in English, Xhosa, Sesotho and Afrikaans. Most participants spoke English. If they preferred to use their first languages, the researcher transcribed the interviews into English. Data were analysed thematically following the phases outlined by Braun and Clarke (2006:87). Both authors were involved in the initial coding and identification of themes. A literature control was done to verify themes and sub-themes.

\section{Ethics}

The Human Research Ethics Committee (HREC) of the university where the first author was a $\mathrm{PhD}$ student approved and monitored the study. The ethical considerations for this research were also guided by the authors' profession as social workers as they adhered to the South African Council for Social Work Service Profession's Code of Conduct (2007). Legal permission to access the abuse register to identify possible participants was granted by the Department of Social Development (DSD) in the Free State Province, South Africa.

The participants were a high-risk group. To counteract emotional and psychological harm, possible risks and precautions were discussed with participants as suggested by Kaplan, Kuhnt and Steinert (2020:2). Numbers were used to identify participants to maintain confidentiality and no identifying information was indicated on transcripts. As is common in research, participants were reassured about their right to withdraw at any time and they had access to a social worker to provide support after data collection. Prolonged contact with participants offered some protection.

\section{FINDINGS}

\section{Participants}

This study was conducted in resource-poor settings in Bloemfontein, Free State province, South Africa. Most participants lived in informal settlements and relied on government pensions. Due to the sensitivity of the research and the prolonged contact with participants, it was important that the primary researcher had easy access to the participants. This made referral and follow-up services possible. It was clear from the cases on the DSD register that elder abuse was a pervasive problem in the area.

Six participants were in their 60s, eight were in their 70s and one participant was 80 years old. Eight participants lived on their own in their own structures in informal settlements. Some of these structures were built with corrugated iron. Four of the victims stayed with their children and grandchildren, one with a caregiver and the other with relatives. One of those participants lived outside in a shack built with corrugated iron as there was no room for her in the house. One man was a caretaker for a rental house. Scholastic qualifications were generally low, with nine participants who only had some form of primary school education. Two had diplomas in teaching. In terms of ethnicity, 11 participants were Sesothospeaking and two were Xhosa-speaking. Two participants were Afrikaans-speaking. 
TABLE 1

PROFILE OF PARTICIPANTS

\begin{tabular}{|c|c|c|c|c|c|}
\hline $\begin{array}{l}\text { Participant and } \\
\text { gender } \\
\text { F - Female } \\
\text { M - Male } \\
\end{array}$ & Age & Ethnicity & $\begin{array}{l}\text { Highest } \\
\text { qualification }\end{array}$ & Type of abuse & Living status \\
\hline VOP1 F & 63 & African & Standard 2 & $\begin{array}{l}\text { Physically abused by own } \\
\text { daughter }\end{array}$ & Living alone \\
\hline VOP2 F & 80 & African & Diploma & $\begin{array}{l}\text { Disabled and in a } \\
\text { wheelchair } \\
\text { Physically abused by son } \\
\text { and granddaughter }\end{array}$ & $\begin{array}{l}\text { Lives with son, daughter, } \\
\text { caregiver, and } \\
\text { grandchildren }\end{array}$ \\
\hline VOP3 F & 79 & Coloured & Standard 1 & $\begin{array}{l}\text { Physically abused by } \\
\text { granddaughter }\end{array}$ & Lives with granddaughter \\
\hline VOP4 F & 66 & African & Standard 4 & $\begin{array}{l}\text { Sexually abused by a } \\
\text { known perpetrator }\end{array}$ & Living alone \\
\hline VOP5 F & 70 & African & Standard 2 & $\begin{array}{l}\text { Physically and sexually } \\
\text { abused by three strangers }\end{array}$ & $\begin{array}{l}\text { Lives with nephew and his } \\
\text { wife }\end{array}$ \\
\hline VOP6 F & 74 & African & Standard 6 & $\begin{array}{l}\text { Sexually abused by a } \\
\text { known perpetrator }\end{array}$ & Living alone \\
\hline VOP7 F & 79 & African & Diploma & $\begin{array}{l}\text { Sexually abused by her } \\
\text { own son }\end{array}$ & Lives with son \\
\hline VOP8 F & 77 & African & Standard 4 & $\begin{array}{l}\text { Sexually abused by a } \\
\text { known perpetrator }\end{array}$ & Lives with two children \\
\hline VOP9 $\mathrm{M}$ & 68 & White & Standard 10 & $\begin{array}{l}\text { Physically abused by the } \\
\text { landlord }\end{array}$ & Living alone \\
\hline VOP10 F & 70 & African & Standard 2 & $\begin{array}{l}\text { Sexually abused by a } \\
\text { stranger }\end{array}$ & Living alone \\
\hline VOP11 F & 65 & African & Standard 3 & $\begin{array}{l}\text { Physically abused by her } \\
\text { own son and daughter } \\
\text { (when they are drunk) }\end{array}$ & Living with two children \\
\hline VOP12 F & 63 & African & Standard 1 & $\begin{array}{l}\text { Physically abused by a } \\
\text { stranger }\end{array}$ & Living alone \\
\hline VOP13 M & 72 & African & Standard 6 & $\begin{array}{l}\text { Disabled and in a } \\
\text { wheelchair Physically } \\
\text { abused by caregiver }\end{array}$ & Lives with caregiver \\
\hline VOP14 F & 74 & African & Standard 2 & $\begin{array}{l}\text { Sexually abused by two } \\
\text { females }\end{array}$ & Living alone \\
\hline VOP15 F & 62 & African & Standard 4 & $\begin{array}{l}\text { Sexually abused by a } \\
\text { stranger }\end{array}$ & Living alone \\
\hline
\end{tabular}

\section{Types of elder abuse}

In this study older persons shared their experiences of sexual and physical abuse. Seven participants were exposed to physical abuse, one to physical and sexual abuse and seven to sexual abuse.

\section{Sexual abuse}

VOP4, VOP6 and VOP8 knew the perpetrators as children who grew up in the same area. Four participants were sexually abused by strangers who entered their homes while they were sleeping. One participant (VOP7) was abused by his own son. VOP5, who lived outside in a shack, was physically and sexually abused by three perpetrators. She was left with serious physical and psychological consequences. 
VOP10 referred to her situation as an ongoing curse and explained that even the way she conceived her children was abusive as her husband forced himself on her aggressively without her consent, which was in effect rape. Elder abuse can aggravate memories of previous adverse life events in the chronosystem as explained by VOP5:

This pain of sexual abuse is less than the pain I experienced from the person I loved dearly as he abused me physically and sexually; you can just imagine. He insulted me every day. I lost respect and dignity from neighbours. I was just nothing as he humiliated me in public.

One male participant in this study (VOP13) was misled by two females who followed him home from the taxi on pension day and pretended to help him carry his bags. They used alcohol together and he fell asleep. When he woke up, they were gone and he discovered that they had abused him sexually while he was asleep. They also robbed him of his pension money, causing material deprivation with consequent resource loss. VOP5 shared facts related to the sexual abuse: "When I opened my eyes I find them already inside. I tried to fight but they were two. They left me dizzy and I could not wake up." VOP10 shared her experience: "When they finished to make turns [sexually abusing her] they ran away leaving me there feeling dizzy and devastated".

Sexual abuse has lasting traumatic effects (Hester \& Lilley, 2018:314). Petersson and Plantin (2019:373) point out that sexual abuse can challenge male victims' views of masculinity and sexuality. Lopez Levers (2012:1) states that some traumatic experiences are unspeakable as the victim is unable to describe the cruelty of the assault, which can hamper disclosure and reporting (DeLaet \& Mills, 2018:497; Hanson \& Wallis, 2018:1066). Traditionally in African societies parents were not comfortable talking about sex with their children and open discussions about sex issues were not acceptable (Motsomi et al., 2016:2). This inability to talk about sex can affect older persons in South Africa when they struggle to talk about sexual abuse. Although silence may be a response to shame, it opens the way for abuse to be repeated (Rada, 2020:3).

The recounting of traumatic stressors over time in the life history of VOP5 and VOP 10 fits within Bronfenbrenner's conceptualisation of the chronosystem (Rosa \& Tudge, 2013:253). Just as current influences in the environment can affect individuals positively or negatively, so historical influences over time, from the macro level such as structural discrimination and on the micro level such as ongoing interpersonal violence in the home, can affect current day-to-day functioning and coping with new traumatic stressors.

\section{Physical abuse}

The seven participants who were physically abused described their experiences. VOP2 was smacked and her hair was pulled by her granddaughter. VOP3 and VOP11 were assaulted and pushed by their own children when the children were drunk. There were no external injuries, although they reported that at times they feel body aches as they fell hard to the ground. VOP9 was assaulted by his landlord. He broke his arm and sustained bruises. He was hospitalised for a week. VOP2 and VOP13 are in wheelchairs and need assistance for everything. VOP13 was slapped by her caregiver, but did not sustain any injuries. VOP2's son constantly subjects her to verbal abuse by insulting her. He would also shake her while she is asleep. VOP5, who was raped by three men, was also assaulted and stabbed in the head with a sharp object.

According to Carney (2020:6), physical abuse puts older persons at a disadvantage as they often lack the physical strength to fight back. The experience of VOP9 confirms this: "This man klapped [slapped] me whilst I was turning away from him after we had a quarrel... I lost balance and I fell down. No one stopped him (cried bitterly)." Physical abuse of older persons by children and grandchildren is more common when such family members are using drugs. VOP11 confirmed that: "When my children are drunk, they shout and pushes me even if we are outside the house." People who abuse substances may lack judgment and discernment (Bandow, 2012:261) which could lead to elder abuse. When this happens 
in the homes and neighbourhoods of older persons, the microsystem becomes a dangerous and unsafe place.

\section{Theme 1: Metaphors used to describe trauma}

Van der Merwe (2005:42) referred to the seminal work of Lakoff and Johnson (1980:5), who describe a metaphor as "understanding and experiencing one thing in terms of another." According to Van der Merwe (2005:42), metaphors can be presented positively or negatively and said that "negatively toned would be 'I am sliding down' versus a positively toned metaphor such as 'I am climbing out of the pit'." Metaphors are grounded in a range of bodily, social and cultural experiences and create meaning in the construction of knowledge and understanding of reality (Munday, Newton-John \& Kneebone, 2020:815). Metaphors were verbalised as follows by participants:

FIGURE 1

METAPHORS

\begin{tabular}{|c|c|c|}
\hline Participant & Metaphor & Elaboration by participants \\
\hline VOP1 & Life is like a desert & $\begin{array}{l}\text { The desert surrounds every step you take - you } \\
\text { walk forever thirsty }\end{array}$ \\
\hline VOP3 & Life is like a rock on your toe & Life is painful as it brings hard moments \\
\hline VOP4 & Life is like a highway & $\begin{array}{l}\text { We all travel our own roads; some are bad and } \\
\text { some are good }\end{array}$ \\
\hline VOP5 & Life is like the strong sea waves & $\begin{array}{l}\text { Life challenges are never-ending and they keep } \\
\text { on coming }\end{array}$ \\
\hline VOP 6 & ubomi ngumzamo" (life is a struggle) & $\begin{array}{l}\text { We are continually suffering but we keep on } \\
\text { trying }\end{array}$ \\
\hline VOP8 & $\begin{array}{l}\text { Life is like a pricking pain in someone's } \\
\text { heart }\end{array}$ & $\begin{array}{l}\text { We do not know what is going to happen } \\
\text { tomorrow }\end{array}$ \\
\hline VOP9: & $\begin{array}{l}\text { Ifeel like I am dumped in a rubbish bin } \\
\text { and useless as I have been used and } \\
\text { abused }\end{array}$ & Does not feel worthy nor valued due to the abuse \\
\hline VOP11 & Life is like winter without fire & $\begin{array}{l}\text { When challenges come, you feel cold even if it } \\
\text { is hot }\end{array}$ \\
\hline VOP12 & Life is a night owl & $\begin{array}{l}\text { We are prone to life dangers as we do not know } \\
\text { what is going to happen in future }\end{array}$ \\
\hline VOP13 & $\begin{array}{l}\text { Life is like an overwhelming amount of } \\
\text { snow }\end{array}$ & $\begin{array}{l}\text { When bad things happen, you feel empty, sad } \\
\text { and devoid of love }\end{array}$ \\
\hline VOP14 & Life is like a mountain & $\begin{array}{l}\text { It is at the top of the mountain that you realise } \\
\text { that there is another mountain as things happen } \\
\text { without being planned }\end{array}$ \\
\hline VOP15 & Life is like a sunset & $\begin{array}{l}\text { It is better to enjoy life whilst it's coming } \\
\text { because the beauty of it is fleeting }\end{array}$ \\
\hline
\end{tabular}

Semino, Demjen and Demmen, (2018:626) point to two integral features of metaphors, namely positioning and journey. Positioning metaphors link with Lakoff and Johnson's (1980, cited by Van der Merwe, 2005:42) orientation metaphor which refers to the spatial relationship, i.e. "dumped in a rubbish bin" (VOP9). Positioning metaphors used by participants as indicated in Table 2 are, for instance, that the trauma is like a setting sun, a rock on the toe, a mountain, winter without fire or a desert. The mountain metaphor is also in part a journey metaphor, in that when you climb the mountain and get to the top, you see another mountain which points to the difficulty of the journey. Lakoff and Johnson (1980, cited by Van der Merwe, 2005:42) referred to physical metaphors which are linked to objects. VOP1 referred to 
a desert, VOP3 to a rock on the toe, VOP5 to strong sea waves, VOP12 to life as a night owl, VOP13 to an overwhelming amount of snow, VOP14 to a mountain and VOP15 to a sunset. All of these metaphors have elements of physical metaphors.

Metaphors are helpful to externalise painful experiences and provide a language that can be used in intervention (Van der Merwe, 2005:43). Whitney (2012:2) describes metaphors as "therapeutic vehicles" that can help with "re-authoring" of the trauma story. Through metaphor VOP9 could express intense feelings of worthlessness using the metaphor of being dumped in a rubbish bin. This metaphor offers many possibilities for further exploration and assessment by tapping into the metaphor. Questions could be asked such as: "What would help you to get out of the dustbin", "Tell me more about how it feels to be stuck in a dustbin like that." Semino et al. (2018:628) state that: "Metaphors are therefore regarded as important because they reflect and influence how we think about different kinds of experiences, and potentially how we consequently act."

\section{Theme 2: Multidimensional reactions}

Ford and Courtois (2020:4) refer to the "life-altering psychophysiological harm" caused by traumatic events. Traumatic exposure has multidimensional effects (Williams \& Poijula, 2016:17), including intrusive memories in the form of flashbacks and repetitive thoughts. Avoidance reactions can be internal when people avoid thinking or talking about the event, or external when they avoid people, places or activities.

In the past two decades there has been a better understanding of the physiological impact of trauma. Many texts are available on the neurobiology of trauma. In this regard Van der Kolk (2014:2) talks about the "recalibration of the body's alarm system" (amygdala) which is needed in the aftermath of trauma.

Participants typically mentioned different feelings and experiences at the same time, as illustrated by the quote of VOP5: "I had mixed feelings, I was angry, disappointed and ashamed. "It is difficult to separate participant quotes clearly into the different reactions. In some of the quotes mentioned here, there will therefore be a number of feelings or thoughts. It was clear from the discussions that there were multidimensional reactions. As could be expected, there were reactions on behavioural, spiritual, physical, sensory and relational levels.

\section{Stigma, shame and loss of dignity}

Elder abuse affects quality of life and dignity negatively as the experience is shameful and humiliating (Mysyuk et al., 2016:698). Hillier and Barrow (2017:38) refer to the loss of a sense of self which can occur in older persons due to increasing frailty, but also from the societal or macro-system level due to negative stereotypes about ageing. Embarrassment and feeling stigmatised are common responses following sexual abuse (Gewirtz-Meydan et al., 2019:3).

Elder abuse strips away dignity, as highlighted by the following participants: VOP11 explained her experience: "I lost dignity through my children. My family has lost respect on me. I am no longer consulted for anything that is happening in my family. It's worse with the community - they act as if I do not exist." VOP14 indicated that: "I am still frustrated - even today I don't think that I will ever be right; it's better if I can die. I feel dirty and smelling." VOP4 indicated that the "rape knocked me down; I felt embarrassed and I hated myself."

VOP12 recounted her feeling of worthlessness and shame as follows: "I am not worthy. I feel ashamed and scared to see people." Pointing to stigma, VOP7 said: "I did not tell anyone. I was afraid that my son would repeat it." VOP9 mentioned self-blame: "I was blaming myself for everything that happened to me; even for being assaulted by a young man."

Hillier and Barrow (2017:38) place the process of ageing in a societal context, saying that human beings are interdependent and partially obtain their sense of self from their social environment, which is most often in the micro system. If they are abused in this social environment, it affects their sense of self, 
dignity and self-worth significantly, which would lead to loss of psychological resources, as indicated by Greenfield (2012:2).

Older persons have learned from societal views and responses that sexual abuse carries a stigma (Kennedy \& Prock, 2016:2). Van der Kolk (2014:2) describes the difficulty of living with trauma and the accompanying shame of "utter weakness and vulnerability." Human responses to trauma do not only result in self-blame but also lead to feelings of social betrayal (Birrell, Bernstein \& Freyd, 2017:30).

\section{Shattered assumptions}

Janoff-Bulman (2002:4) wrote about how trauma exposure shatters basic assumptions and talks about "the core of our internal world" where people hold assumptions about themselves and the world. It can be expected that older persons' assumptions and conceptual systems have been shaped by a lifetime of positive and negative experiences in the chronosystem context. It is not clear how the fundamental assumptions of an older person, living in South Africa, in a resource-poor setting will be shaped. The ideal assumption would probably be that an older person will live in peace, surrounded by a caring family and community members, in a safe micro system where basic needs are met also from macro system level with adequate safeguarding mechanisms and social security. If an extremely traumatic event such as physical or sexual abuse occurs in this later life stage, it can create a new existential crisis.

Some participants touched on aspects related to shattered assumptions and the meaning of life. VOP8 indicated that "abuse takes away life joy; when I was raped I thought that was the end of the world." According to VOP6: "On TV we watch scaring things, not knowing that you are the next." After six sessions of intervention, it seems as if there was a positive shift in the assumptive world of VOP9 when he said: "I feel I have been awaken[ed] from a deep sleep. We need to stop crying about how we have been hurt and recapture the playful spirit of the child in our hearts." VOP5 showed a need to move beyond the trauma: "I cannot live in the past. I have forgiven or I am trying, whoever that hurt me. I want to have peace. I cannot take more stress." VOP3 also indicated after the intervention that: "I have made peace with that [the sexual abuse] and I am beginning to accept that reality." VOP7 reiterated that: "It doesn't matter whether the water is cold or warm; you have to cross anyway. Whether there are bad things that are happening in our lives, we have to live anyway. We need people to lift us up and remind us that the journey still continues." VOP9 echoed that: "Life is not a written book that you can pick up and read; it is a journal waiting for you to fill in the pages. As I grow older I have learned that every day nature paints a sunset whether you are there to appreciate or not. Life is for living; give it a try, not everybody is bad. I can meet nice people and build relationships and go on." The quotes by participants show wisdom, probably from lessons learned over their life span.

\section{Sleeping problems and nightmares}

Traumatic events can lead to sleep disturbances and nightmares (Belleville, Dubé-Frenette \& Rousseau, 2019:1; Chaurasia \& Srivastava, 2020:6; Malaktaris \& Lynns, 2019:251; Nobakht \& Dale, 2019:79). Williams and Poijula (2016:213) link sleeping problems with the over-stimulation of the autonomic nervous system during and after trauma. VOP3 stated that: "When I imagine the attack by my grandchild, I can't sleep and at times I have nightmares." VOP8 confirms that: "Even now I do not sleep well as my grandchildren often wakes me up saying I am crying; I have nightmares. Fear of recurrence can be linked to sleeping problems as indicated by VOP2: "I am always anxious because I do not know what she is going to do next, I don't sleep well. " In this regard VOP10 mentioned that "I wake up and check windows in the evening as I always fear that they will come again; that boy is out on bail." According to Fang et al. (2018:2325), sleep disturbance can lead to extreme tiredness and depression.

\section{Fear, anxiety and loss of sense of safety}

Max-Neef (1991:32) points to protection and safety as fundamental human needs. Gordon (2019:40) talks about "storms of fear" created by traumatic exposure in the amygdala and indicates that such fears suppress the cognitive, frontal parts of the brain which could potentially moderate such fears with logical thinking. It is to be expected that a sense of emotional and physical safety will be lost after exposure to 
elder abuse, as indicated by VOP15: "I don't feel safe anymore, I wish I can have money and buy an iron door." Being safe as an older person is not only about physical safety, but it is about the general atmosphere of feeling safe in the microsystem as articulated by VOP 2: "I wanted to move from my house and stay with relatives as I am at risk (sobbed bitterly). Come and see - the thugs were removing the door frame whilst I was sleeping. I am scared; I don't feel safe."

Anxiety can leave victims emotionally and physically frail and limit their movement and activities. VOP8 indicated that "I always feel anxious especially when I walk alone. I feel like somebody is following me. Last week I waked up in hospital. They say I fell down as I was [walking] from the shop." Feelings of fear and anxiety strain victims' adaptation as explained by VOP10: "When I think about this, I cannot even eat. I am nervous." VOP7 indicated that "I am always anxious as this [abuse] will happen again." VOP1 emphasises that "We don't feel safe; we feel anxious as we are abused by our children." It is clear from the descriptions of participants that they are vulnerable due to being frail, but also because they live in structures where it is easy to remove doors and windows and to gain entry into their homes. Their fears seem to be realistically based on their unsafe environments.

\section{Flashbacks}

According to Malaktaris and Lynns (2019:251), flashbacks are linked to the sensory experience of the event and reminders can trigger re-experience of core features of the traumatic event, as in the case of VOP6 who mentioned that: "I hate to see a young man. I just become angry." Some people become flooded with the emotions that they felt at the time of trauma, as explained by VOP14: "When this thing comes [memories and flashbacks] I feel like screaming. I can see that young boy in the dark still coming to me. I am scared they will come again". During flashbacks intrusive memories linked to trauma are reexperienced (Sachschal et al., 2019:1033).

\section{Isolation and avoidance}

The responses by VOP15: "I have lost interest in everything. I just want to be alone" and VOP6: "Ever since I was sexually abused I do not like to see people - as if they are looking at me for what happened" show that elder abuse can lead top social isolation at a time when social support can be a mitigating factor (Kaspiew, Carson \& Rhoades, 2016:98). VOP10 said something interesting that indicates that cultural and family values can also influence the way people talk about trauma: "You know we were taught like that as children by our parents that you do not talk about bad thing; for instance, when you share your pain, people will say she is not even ashamed, she is talking about it." Such perceptions can lead to the further isolation and withdrawal of abused older persons. Consequently, vulnerable individuals are not supported in the microsystems where they live and they can become withdrawn, isolated (Lien et al., 2016:195) and left to deal with the adverse experiences of elder abuse on their own.

\section{Spiritual-religious aspects}

Harris et al. (2015:174) discuss spirituality in the context of trauma. Spirituality and religion are often linked to the search for meaning or the search for reasons why traumatic events happened. Manda (2015:1) argues that a bio-psychosocial approach to trauma is not inclusive enough and that spiritual effects should be included in the understanding of trauma.

It was clear from this research that participants were affected on spiritual and religious levels. With cumulative stress and trauma, some older persons think they are punished by God for their sins (Malone \& Dadswell, 2018:2) as indicated by VOP5:

This incident has aggravated the abusive life I have lived in my marriage as my husband was never romantic, but will just throw himself over me whenever he wanted sex. I am asking God 'what have I done to suffer so much?'

Older persons' spirituality typically grows as they age and as they move towards the end of life (Malone \& Dadswell, 2018:4). VOP10 had existential questions, asking: "Is it the way that God is punishing me? I am having questions that nobody is answering." People can also use their faith to manage difficult 
situations as was clear from the statement of VOP4: "We thank God for His mercy." While participants had questions on religious level, religion was also an important resource as indicated by De La Porte and Nzeku (2015:192). Where people do not have many tangible resources, religion and support from church members can counteract resource loss in the aftermath of trauma.

\section{Theme 3: Revenge and social justice}

According to Goldner, Lev-Wiesel and Simon (2019:2), revenge fantasies are based on an innate human desire to get even with a perpetrator. Usually the desire for revenge is caused by the experience of humiliation, unjust harm or anger inflicted by another person, as explained by VOP9, who was physically assaulted and spent three days in hospital with serious injuries: "I was locked in police cells for the weekend as he opened a case of assault." This injustice led to thoughts of revenge as VOP9 indicated: "At times I feel like waking up and go to that house and fight that man, I will kill him with my hands." In terms of justice he said: "How can they throw my case out claiming that I do not have a witness? To our disappointment (me and my lawyer) the court threw out the case as I had no witness". I was so hurt because I knew that I have not done anything."

A sense of injustice leaves older persons feeling powerless with unresolved anger and shame, as was clear from the statement of VOP10: "But there is nothing happening [with judicial processes]; especially if it is the abuse of an older person our cases disappear. "Seemingly VOP15's experience is the same as that of other victims as she confirms that: "I have not heard anything from the police; there is nothing. It's [legal process] going for a year now. I don't think the case is still on. On that day the police told me that I will hear from my investigating officer; I never heard anything." The helplessness and powerlessness which follows traumatic exposure can also lead to "the pseudo-power of revenge fantasies" (Lillie \& Strelan, 2016 as cited by Goldner et al., 2019:n.p). Goldner et al. (2019:n.p) importantly state that a sense of injustice can serve as an "internal mechanism for evoking a desire for revenge and associated fantasies, which may endow the victim with a sense of control after the trauma". These authors reframe revenge fantasies and a sense of injustice as stepping stones in the process of trauma integration and coming to terms with what happened.

\section{Theme 4: Support}

Social support has consistently been pointed out as a core protective variable in the post-trauma period (Gordon, 2019:98; Pillemer et al., 2016:196).

\section{Social support and relational aspects}

The protection and care of older persons should be a priority in their homes and communities (micro and meso systems). However, it is often within these systems where older persons are abused. The importance of reciprocal help by neighbours in times of crisis is widely acknowledged (Seifert \& König, 2019:2). Neighbours are best suited for tasks that require immediate response and ubuntu as encapsulated by VOP3: "I got angry and helpless and I tried to cry but he put his hand over my mouth. I was saved by the community. Neighbours and the community shared the pain as they were angry with what has happened." Linked to this, VOP5 indicated that: "My neighbours called the police. I was taken to hospital."

The community also fights back in support of the older person as explained by VOP6: "The case was reported to the police by community members after they beat him." It seems that neighbours are responsive, as encapsulated by VOP10: "That evening when he left I screamed and the neighbours came... one of them took me to hospital... they checked on me, shame, they were sorry for what happened to me." Some older persons disclose their trauma to their neighbours, as explained by VOP13: "I told my neighbour who suggested that I must report the case to the police." In resource-poor settings houses or informal structures are typically built close to each other. Neighbours would be the ideal people to watch out for the safety and welfare of older people.

Some older persons need the emotional and physical safety offered by family members after elder abuse, as stated by VOP1:" I wanted to move from my house and stay with relatives as I am at risk." Almira, 
Hanum and Menaldi (2019:2) and Khondoker et al. (2017:100) confirm that emotional and physical security within the extended family provide care and support to older persons during times of distress. Thomas and Umberson (2018:1133) are of the view that the parent-child relationship is important for older persons as their social network ties diminish with age. Most adult children play a pivotal role with their ageing parents, as explained by VOP12: "I reported the case to my children because already the caregiver absconded and I had no one to stay with. My son was there for me." In the same vein VOP14 indicated that: "I was glad to hear my son shouting at the door. I cried and told him I was raped." Victims of elder abuse that have a strong relationship with their children receive better care and support from them (Khondoker et al., 2017:100). Clearly social support and strong relationships with neighbours and family members are mitigating factors in the face of adversity which can diminish the impact of resourceloss cycles.

\section{Formal support}

In South Africa there is legislation, and a Protocol on management of elder abuse (Department of Social Development, 2010:3). The Protocol is a joint interdisciplinary and inter-sectoral management framework for elder abuse intervention. However, the victims of elder abuse are not satisfied, as indicated by VOP10: "Social workers need to improve coordination, inter-collaboration, establish multidisciplinary team and provide care and support by making follow-ups with their clients. "VOP11 stressed that: "Social workers should make follow-up as they promised to come and finalise their cases. You know ever since then I have been waiting." VOP12 added that "Social workers should attend to cases when reported to them - we don't know social workers in this area." It seems there are limited resources to fulfil the objectives of the Protocol as suggested by participant VOP12: "My children reported the matter telephonically to social workers but they did not come. They said at the time there was no transport." In the same vein VOP13 said that "I thought maybe social workers will come to see me and hear what happened." Participant VOP5 is of opinion that: "Social workers should give counselling and shelter. You know, here in squatter camps we do not know each other and there are no lights - maybe social workers can talk to government."

Older persons often do not know the role of a social worker, as indicated by VOP14: "I don't know the work of social workers. Sometime ago, I do not know which year, I heard that they were giving food parcels - maybe if they can give me one". Social work roles and responsibilities are not always understood, not only by older persons but also by politicians, other government departments and society (Proctor, 2017:346).

Ideally, social workers should be specially trained to provide effective support after elder abuse, as they are at the forefront of services to affected older persons (Putnam, 2015:230). Ray et al. (2015:1303) suggest that a social worker allocated for a case of elder abuse should conduct a home visit to do a full assessment that includes the risk of further abuse, cognitive ability and the older person's independence. During the process the social worker should attend to the basic needs including care, safety and security, support networks and respite care. Humble et al. (2013:250) suggest that to successfully attend to abuse cases, social workers have to use available resources effectively. When older persons wait in vain for a response from police, the justice system or social workers, this can aggravate a sense of trauma-related despair and helplessness.

\section{DISCUSSION}

From a bio-ecological perspective it is clear that elder abuse is multifaceted. Abused older persons have histories of personal life experiences and societal influences or collective life issues. These chronosystem-related life experiences form individuals, can shape their current realities and the way they deal with the trauma of elder abuse. In resource-poor settings older persons live in persistently harsh environments with limited tangible and non-tangible resources. Elder abuse can place them in downward spirals of resource loss. 
The findings highlight that older persons are abused in the very micro systems where they should be safe and protected. Whereas traumatic exposure can lead to shattered assumptions and changed worldviews, this is probably even more true when abuse happens at the hands of family members or people known to the older person. It was found that neighbours offered strong informal support, sometimes already in the immediate aftermath of the abuse. This type of informal support is an avenue of help that could be explored and expanded. It was evident that shame and stigma prevent abused older persons from talking about their experiences. In this study the use of metaphor offered an avenue to explore, reframe and externalise the experiences of participants.

Participants did not have clarity about the role of social workers. Even more worrying is that the participants received almost no interventions from social workers. There should be consistent and coordinated social work services offered to abused older persons, especially in the light of the serious multidimensional reactions to elder abuse described in this article.

On macro-system level, potential protection offered by the South African Constitution, policies and legislation did not translate into action and services for the participants of this study. Findings show that broader exo-systems fail abused older persons. They seem to be caught up in a waiting game - waiting to hear from police, and waiting for justice to take its course. It was clear from the accounts of participants that there was much room for improvement in terms of feedback and follow-up of these cases of elder abuse from the side of the police and the judicial system. There should be concerted efforts by all role players to prioritise elder abuse in the legal and criminal justice systems. A case manager for every elder abuse case, which should ideally be a social worker, should oversee each case of elder abuse to ensure adequate follow-up, court preparation of the older person and to generally ensure that justice is served. The case manager should ensure that the older person is physically safe and cared for after the abuse and that there is provision of social work intervention in resource-poor settings. Social workers should stimulate elder abuse debates in communities and offer continuous education and community awareness programmes to prevent elder abuse.

\section{CONCLUSION}

The global population is ageing and with that elder abuse is rapidly increasing. In this article the voices of abused older persons were heard. Their raw pain and distress were clear from their honest accounts of their experiences. Victims of elder abuse live with fear, shame and a loss of dignity. Embeddedness is a widely used term in bio-ecological theory. It denotes a sense of safety and being nested in a protective environment. In contrast to this, a participant felt as if he was useless and dumped in a rubbish bin after being abused. Multi-sectoral efforts should be aimed at preventing elder abuse from happening in the first place. In the unfortunate event of elder abuse happening, all efforts should be aimed at supporting victims to prevent them from feeling like this participant. Risk factors such as societal attitudes and violence should be addressed from micro to macro levels to restore the perception of older persons as valued members of society who should be protected.

\section{REFERENCES}

ALMIRA, L., HANUM, L., \& MENALDI, A. 2019. Relationships with children and the psychological well-being of the elderly in Indonesia. SAGE Open Medicine, 7:1-6. https://doi.org/10.1177/2050312119836026

BAILEY, T.D. \& BROWN, L.S. 2020. Complex trauma: Missed and misdiagnosis in forensic evaluations. Psychological Injury and Law, 13 (2):109. doi: 10. 1007/s12207-020-09383-w.

BANDOW, D. 2012. From fighting the drug war to protecting the right to use drugs. Recognising a forgotten liberty. Mexico: Fraser Institute.

BARBELET, V. 2018. Older people in displacement: Falling through the cracks of emergency responses. Humanitarian policy group, Overseas Development Institute. Help Age International. 
BELLEVILLE, G., DUBé-FRENETTE, M. \& ROUSSEAU, A. 2019. Sleep disturbance and nightmares in victims of sexual abuse with post-traumatic stress disorder: An analysis of abuse-related characteristics. European Journal of Psychotraumatology, 10(1):1581019. doi: 10. 1080/20008198.2019.1581019

BIRRELL, P.J., BERNSTEIN, R.E., \& FREYD, J.J. 2017. With the fierce and loving embrace of another soul: Finding connection and meaning after the profound disconnection of betrayal trauma. In: ALTMAIER, E.M. (ed.). Reconstructing meaning after trauma: Theory, research and practice. Academic Press.

BRADSHAW, C., ATKINSON, S. \& DOODY, O. 2017. Employing a qualitative descriptive approach in health care research. Global Qualitative Nursing Research, 4:1-8.

BRAUN, V. \& CLARKE, V. 2006. Using thematic analysis in psychology. Qualitative Research in Psychology; 3:77-101.

CARNEY, A. 2020. Elder abuse. Forensic, legal and medical aspects. United Kingdom: Academic Press.

CHAURASIA, H. \& SRIVASTAVA, S. 2020. Abuse, neglect and disrespect against older adults in India. Population Ageing. https://doi.org/10.10007/s 12062-020-09270

CHEN, S., WESTMAN, M. \& HOBFOLL, S.E. 2015. The commerce and crossover of resources: Resource conservation in the service of resilience. Stress and Health, 31:95-105.

CLARK, W. \& KIATES, R. 2008. Exploring sustainability science: A Southern African perspective. Stellenbosch, South Africa. African Sun Media.

REPUBLIC OF SOUTH AFRICA (RSA). 1996. The Constitution of the Republic of South Africa. Act 108 of 1996. Pretoria: Government Printers.

DELAET, D.L. \& MILLS, E. 2018. Discursive silence as a global response to sexual violence: From Title IX to Truth Commissions, Global Society, 32(4):496-519, doi: 10.1080/13600826.2018.1516200

DE LA PORTE, A. \& NZEKU, M. 2015. Narrative practices in trauma care, support and counselling. In: HERBST, A. \& REITSMA, G. (eds.). Trauma counselling. Principles and practice in South Africa today. Cape Town: Juta.

REPUBLIC OF SOUTH AFRICA (RSA). DEPARTMENT OF SOCIAL DEVELOPMENT. 2006. Older persons Act No 13 of 2006. Pretoria: Government Printer.

DEPARTMENT OF SOCIAL DEVELOPMENT. Protocol on Management of Elder Abuse. South Africa.

DEPRINCE, A.P. \& JACKSON, S.L. 2020. Moving the field forward: Elucidating the nexus between elder abuse and trauma. Journal of Trauma and Dissociation, 21(2):151-157. https://doi.org/10.1080/15299732.2020.16924.04

FANG, H., TU, S., SHENH, J. \& SHAO, A. 2018. Depression in sleep disturbance: A review on a bidirectional relationship, mechanisms and treatment. Journal of Cellular and Molecular Medicine, 23:2324-2332. doi: 10. 1111/jcmm. 14170

FORD, J.D. \& COURTOIS, C.A. 2020. Defining and understanding complex trauma and complex traumatic stress disorders. In: FORD, J.D. \& COURTOIS, C.A. (eds.). Treating complex traumatic 
stress disorders in adults. Scientific foundations and therapeutic models. $2^{\text {nd }}$ ed. New York: The Guilford Press.

FRISOLI, A. 2016. The South African elderly: Neglect, social contribution and the HIV/AIDS epidemic. University of New York. (M thesis)

GEWIRTZ-MEYDAN, A., LAHAV, Y., WALSH, W. \& FINKELHOR, D. 2019. Psychopathology among adult survivors of child pornography. Child Abuse and Neglect, 98: 104-189.

GITTERMAN, A. 2017. Life model of social work practice. In: TURNER, F.J. (ed.). Social work treatment. Interlocking theoretical approaches. $6^{\text {th }}$ ed. New York, NY: Oxford University Press.

GOLDNER, L., LEV-WIESEL, R \& SIMON, G. 2019. Revenge fantasies after experiencing traumatic events: Sex differences. Frontiers in Psychology, 9886:1-9 doi:10.3389/fpsyg.2019.00886

GOODRICK, W. \& PELSER, A. 2014. The greying of a rainbow nation: policy responses to the implications of population ageing in South Africa. Supplement on population issues in South Africa, 28(1):648-660.

GORDON, J. 2019. Transforming trauma. Discovering wholeness and healing after trauma. London, Yellow Kite Books.

GREENFIELD, E.A. 2012. Using ecological frameworks to advance a field of research, practice and policy on Aging-in-Place initiatives, Gerontologist, 52(1):1-12.

HAMMARBERG, K., KIRKMAN, M. \& DE LACEY, S. 2016. Qualitative research methods: When to use them and how to judge them, Human Reproduction, 31(3):498-501.

HANSON, R.E. \& WALLIS, E. 2018. Treating victims of sexual abuse. American Journal of Psychiatry, 175:1064-1070 doi. 10.1176/appi/apj.2018.18050518

HARRIS, J.L., LEAK, G.K., DUBKE, R. \& VOECKS, C. 2015. Religious strain and post conventional religiousness in trauma survivors. Psychology of Religion and Spirituality, 7(2):173-178.

HESTER, M. \& LILLEY, S. 2018. More than support to court: Rape victims and specialist sexual violence services. International Review of Victimology, 24(3):313-328.

HILLIER, S.M. \& BARROW, G.M. 2015. Aging, the individual and society. Stamford: Cengage learning.

HILLIER, S.M. \& BARROW, G.M. 2017. Aging, the individual and society. $10^{\text {th }}$ ed. Stamford: Cengage learning.

HOBFOLL, S.E. 2011. Conservation of resource caravans and engaged settings. Journal of Occupational and Organizational Psychology, 84:116-122.

Human Rights Watch, 2016. South Africa: Events of 2016. http://www.hrw.org/worldreport/2017/country-chapters/South Africa

HUMBLE, M.N., LEWIS, M.L., SCOTT, D.L. \& HERZOG, J.R. 2013. Changes in rural social work practice: When Support Groups Contain Your Neighbours, Church Members and the PTA. Journal of Social Work with Groups, 36(2-3):249-258.

JANOFF-BULMAN, R. 1992. Shattered assumptions: Towards a new psychology of trauma. Washington. Free Press.

KALU, F.A. \& BWALYA, J.C. 2017. What makes qualitative research good research? An exploratory analysis of critical elements. International Journal of Social Science Research, 5(2):43-56. 
KAPLAN, L., KUHNT, J. \& STEINERT, J. 2020. Do no harm? Field research in the global South: Ethical challenges faced by research staff. World Development, 127:104810. doi: 10.1016/worlddev.2019.104810

KASPIEW, R., CARSON, R. \& RHOADES, H. 2016. Elder abuse: Understanding issues, frameworks and responses. Melbourne: Australian Institute of Family Studies. Research report No 35.

KENNEDY, A.C. \& PROCK, A.K. 2016. "I still feel like I am not normal": A review of the role of stigma and stigmatization among female survivors of child sexual abuse, sexual assault, and intimate partner violence. Trauma, Violence \& Abuse, 19(5):512-527.

KHONDOKER, M., RAFNSSON, S.B. MORRIS, S., ORELL, M. \& STEPTOE, A. 2017. Positive and negative experiences of social support and risk of dementia in later life: an investigation using the English longitudinal study of ageing. Journal of Alzheimer's Disease, 58:99-108. doi: 10. 3233/JAD-161160

KOTZÉ C. 2018. Elder abuse. The current state of research in South Africa. Frontiers in public health, 6:358. https://doi.org/10.3389/fpubh.2018.00358

KUMAR, A. 2016. Older people's experiences and perspective of elder abuse: What next. Age and Aging, 45:572-573. https://doi.org/10.1093/ageing/afw121

LAMB, S., ROBBINS-RUSZKOWSKI, J. \& CORWIN, A.I. 2017. Introduction. Successful aging as a twenty-first century obsession. In: LAMB, S. (ed.). Successful aging as a contemporary obsession: Global perspectives. New Brunswick: Rutgers University Press.

LIEN, C., ROSEN, T., BLOEMEN, E.M., ABRAMS, R.C., PAVLOU, M. \& LACHS, M.S. 2016. Narratives of self-neglect: Patterns of traumatic personal experiences and maladaptive behaviors in cognitively intact older adults. Journal of American Geriatric Society. 11:195-200.

LOPEZ LEVERS, L. 2012. Trauma counselling theories and intervention. New York: Springer.

MALAKTARIS, A. L., \& LYNN, S. J. 2019. The phenomenology and correlates of flashbacks in individuals with posttraumatic stress symptoms. Clinical Psychological Science, 7(2):249264. https://doi.org/10.1177/2167702618805081

MALONE, J. \& DADSWELL, A. 2018. The role of religion, spirituality and/or belief in positive ageing for older adults. Geriatrics, 3(2):28.

MANDA, C. 2015. Re-authoring life narratives of trauma survivors: Spiritual perspective, HTS Teologiese Studies/Theological Studies, 71(2):1-8.

MATHEW, A. \& NAIR, S.B. 2017. Theoretical perspectives of elder abuse: A framework analysis for abused elderly in Kerala. Journal of Humanities and Social Science, 22(9):29-33.

MAX-NEEF, M. 1991. Human scale development. Conception, application and further reflections. New York, Apex Press.

MOTSOMI, K., MAKANJEE, C., BASERA, T. \& NYASULU, P. 2016. Factors affecting effective communication about sexual and reproductive health issues between parents and adolescents in Zandspruit informal settlement, Johannesburg, South Africa. Pan Medical Journal, 25:120. doi:10.11604/panj.2016.25.120.9208

MUNDAY, I., NEWTON-JOHN, T. \& KNEEBONE, I. 2020. Barbed wire wrapped around my feet: Metaphor use in chronic pain. British Journal of Health Psychology, 25:814-830. doi: 10. 1111/bjhp. 12432

MYSYUK, Y., WESTENDORP, R.G.J. \& LINDENBERG, J. 2016. How older persons explain why they became victims of abuse. Age and Ageing, 45:695-702. doi:10.1093/ageing/afw100 
NOBAKHT, H.N., \& DALE, K.Y. 2019. The mediational roles of sleep disorders and nightmares in the relationship between trauma and dissociation. Dreaming, 29(1):7990. https://doi.org/10.1037/drm0000095

PETERSSON, C. \& PLANTIN, L. 2019. Breaking with norms of masculinity: Men making sense of their experiences of sexual assault. Clinical Social Work Journal, 47:372-383.

PHELAN, A. 2020. Advances in elder abuse research: Practice, legislation, and policy. Switzerland: Springer.

PILLEMER, K., BURNES, D., RIFFIN, C. \& LACHS, M.S. 2016. Elder abuse: Global situation, risk factors and prevention strategies. Gerontologist, 56(2):194-205.

PROCTOR, E. 2017. The pursuit of quality for social work practice: Three generations and counting. Journal of the Society for Social Work and Research, 8(3):335-353. https://doi.org/10.1086/693431

PUTNAM, M. 2015. Replacing elderly with older adults in JGSW Publications, Journal of Gerontological Social Work, 58(3):229-231. doi: 10.108010634372.2015.1033363

RADA, C. 2020. Violence, communication and satisfaction among middle-aged adults and older people from Romania. Humanities \& Social Science Communication, 7:109. https://doi.org/10.1057/s41599020-00594-9

RAY, M., MILNE, A., BEECH, C., PHILLIPS, J.E., RICHARDS, S., SULLIVAN, M.P., TANNER, D. \& LLOYD, L. 2015. Gerontological social work: Reflections on its role, purpose and value. British Journal of Social Work, 45(4):1296-1312.

RISHWORTH, A., ELLIOTT, S. J. \& KANGMENNAANG, J. 2020. Getting old well in Sub Saharan Africa: exploring the social and structural drivers of subjective well-being among elderly men and women in Uganda. International Journal of Environmental Research and Public Health, 17:2347. doi:10.33990/nerph17072347

ROOS, V. \& WHEELER, A. 2016. Older people's experiences of giving and receiving empathy in relation to middle adolescents in rural South Africa. South African Journal of Psychology, 46 (4):517529.

ROSA, E.M. \& TUDGE, J. 2013. Urie Bronfenbrenner's theory of human development: Its evolution from ecology to Bioecology. Journal of Family Theory and Review, 5:243-258.

SACHSCHAL, J., WOODWARD, E., WILCHELMANN, J.M., HAAG, K. \& EHLERS, A. 2019. Differential effects of poor recall and memory disjointedness on trauma symptoms. Clinical Psychological Science, 7(5):1032-1041

SANTOS, A.J. NUNES, B., KISLAYA, I., GIL, A.P. \& RIBERIO, O. 2019. Elder abuse victimization patterns: latent class analysis using perpetrator and abusive behaviour. BMC Geriatrics, 19(117):1-11.

SEIFERT A. \& KÖNIG R. 2019. Help from and help to neighbors among older adults in Europe. Frontiers in Sociology, 4(46):1-13. doi: 10.3389/fsoc.2019.00046

SEMINO, E., DEMJEN, Z. \& DEMMEN, J. 2018. An integrated approach to metaphor and framing in cognition, discourse and practice with an application to metaphors for cancer. Applied Linguistics, 39(5):625-645. doi:10.1093/applin/amw028 
REPUBLIC OF SOUTH AFRICA. (RSA). 2017. Older Persons Amendment Bill. Cape Town: Department of Social Development.

SOUTH AFRICAN COUNCIL FOR SOCIAL WORK SERVICE PROFESSIONS, 2007. Policy guidelines for course of conduct, code of ethics and the rules for social workers. South Africa. Hatfield: Pretoria.

SOUTH AFRICAN HUMAN RIGHTS COMMISSION (SAHR). 2015. Investigative hearing into systematic complaints relating to the treatment of older persons. Johannesburg: SAHRC.

TAYLOR, M. 2014. Trauma therapy and practice. Neuroscience, Gestalt and the body. Berkshire, University Press. McGraw-Hill.

THOMAS, P.A. \& UMBERSON, D. 2018. Do older parents' relationships with their adult children affect cognitive limitations, and does this differ for mothers and fathers? The Journal of Gerontology, 73(6):1133-1142.

VAN DER KOLK, B. 2014. The body keeps the score. Brain, mind, and body in the healing of trauma. New York, Penguin Books.

VAN DER MERWE, M. 2005. A solution-building metaphorical concept for direct social work with children: An exploratory study. Social Work/Maatskaplike Werk, 41(1):39-53.

WELSH, E. 2018. Trauma. survivors' strategies for healing. California: Althea Press.

WHITNEY, M.N. 2012. Using metaphor and narrative ideas in trauma and family therapy. HTS Teologiese Studies/Theological Studies, 68(2):1-5.

WILlIAMS, M.B. \& POIJULA, S. 2016. The PTSD workbook $3^{\text {rd }}$ ed. Oakland, CA: New Harbinger Publications.

WORLD HEALTH ORGANISATION. 2013. Functional decline and dependence in ageing populations, panel side event at 66th World Health Assembly. 2013. http://www.who.int/ageing/events/wha66/en/index.html

YON, Y, MIKTON, C., GASSOUMIS, Z.D. \& WILBER, K.H. 2019. The prevalence of self-reported elder abuse among older women in community settings. A systematic review and meta-analysis. Trauma Violence \& Abuse. 20(2):245-259.

ZAIDI, AS. 2015. Ageing and Development. GSDRC Professional Development Reading Pack no. 25. Birmingham, UK: University of Birmingham. 